\title{
Aspergilloma Paru; Sebuah Laporan Kasus
}

\section{Pulmonary Aspergilloma; A Case Report}

KATA KUNCI

KEYWORDS

ABSTRAK

ABSTRACT
Mega Senja, Irvan Medison, Russilawa‡̇].

Departemen Pulmonologi, dan Kedokteran Respirasi Fakultas Kedokteran Universitas Andalas/RSUP DR. M. Djamil,

Padang, Indonesia

Aspergilloma, mikosis paru, infeksi jamur

Aspergilloma, pulmonary mycosis, fungal infection

Penyakit infeksi sampai saat ini masih menjadi masalah kesehatan utama di Indonesia, salah satu nya adalah infeksi jamur atau mikosis paru. Jenis mikosis paru yang sering dilaporkan adalah Aspergillosis. Diketahui lebih lanjut bahwa Aspergilloma sering ditemui pada pasien-pasien paska tuberkulosis paru. Sebagian besar studi melaporkan kavitas paru pada aspergilloma disebabkan oleh tuberkulosis. Manifestasi klinis aspergilloma paru beragam, mulai dari kasus tanpa gejala hingga hemoptisis masif yang bisa berakibat fatal. Pada laporan kasus ini, penulis menyajikan data kasus dari seorang laki-laki berusia 42 tahun yang telah didiagnosis sebagai aspergilloma paru.

Infectious diseases are still a major health problem in Indonesia, one of which is fungal infection or pulmonary mycosis. A type of pulmonary mycosis that is often excreted is Aspergillosis. Find out more about Aspergilloma often found in patients after pulmonary tuberculosis. Most studies report pulmonary cavity in Aspergilloma caused by tuberculosis. The clinical manifestations of pulmonary aspergilloma are various, from cases without variation to massive hemoptysis which can be fatal. In this case report, the authors present case from a 42year-old male, who had been diagnosed as pulmonary Aspergilloma. 


\section{PENDAHULUAN}

Penyakit infeksi sampai saat ini masih menjadi masalah kesehatan utama di Indonesia, salah satu nya adalah infeksi jamur (mikosis) paru. Jenis mikosis paru yang sering dilaporkan adalah Aspergillosis, yaitu 95\% disebabkan oleh Aspergillus fumigatus. Aspergilloma paru adalah salah satu bentuk klinis dari Aspergillosis, yang dimana Aspergilloma merupakan infeksi jamur saprofit berupa kolonisasi didalam kavitas paru yang dapat disebabkan oleh berbagai penyakit dasar. Kolonisasi ini akan membentuk formasi seperti massa yang disebut fungus ball atau mycetoma. Aspergilloma terdiri dari hifa Aspergillus, fibrin, lendir, sel-sel inflamasi, darah, dan komponen sel epitel-epitel (Rozaliyani et al., 2017).

Aspergilloma sering ditemui pada pasien-pasien paska tuberkulosis paru, baik yang baru sembuh maupun yang telah sembuh dalam periode waktu yang lama. Sebagian besar studi melaporkan kavitas paru pada aspergilloma disebabkan oleh tuberkulosis. Aspergilloma juga ditemukan pada kavitas yang disebabkan oleh berbagai penyakit dasar seperti sarcoidosis, bronkiektasis, kistik fibrosis, kista paru, kanker paru (Brik A et al., 2008).

Manifestasi klinis aspergilloma paru beragam, mulai dari kasus tanpa gejala hingga hemoptisis masif yang bisa berakibat fatal. Oleh karena itu, modalitas terapi yang optimal untuk aspergilloma tergantung pada presentasi klinis. Pembedahan merupakan terapi definitif untuk aspergilloma. Pada pasien hemoptisis ringan dianjurkan tirah baring, postural drainage dan terapi simptomatik lain.
Pada pasien hemoptisis berulang atau masif, pembedahan dilakukan dengan mempertimbangkan risiko/toleransi operasi. Namun pengambilan keputusan reseksi bedah sering terhambat oleh fungsi cadangan paru yang buruk pada aspergilloma. Jika tidak mungkin dilakukan, dapat dipertimbangkan tindakan embolisasi atau pemberian Obat Anti Jamur (OAJ) transtorakal-intrakavitas (Park $S$ et al., 2009).

\section{KASUS}

Seorang laki-laki, usia 42 tahun datang ke IGD dengan keluhan utama batuk darah. Batuk darah meningkat sejak 1 hari sebelum masuk rumah sakit. Volume total darah $\pm 600 \mathrm{cc}$, darah berwarna merah segar. Batuk ada sejak 1 tahun yang lalu, berdahak warna putih encer, batuk bersifat hilang timbul. Keluhan batuk darah sudah dirasakan sejak 4 tahun yang lalu. Keluhan lain pada pasien didapatkan penurunan berat badan, badan kadang kadang terasa lemas. Pasien pernah dirawat dengan keluhan yang sama 6 bulan yang lalu. Pasien memiliki riwayat penyakit $\mathrm{TB}$ paru 8 tahun sebelumnya.

Untuk riwayat sosioekonomi dan kebiasaan pasien, pasien seorang pembuat jok motor yang memiliki kebiasaan merokok 6 batang sehari selama 20 tahun (IB ringan), sudah berhenti sejak 8 tahun yang lalu (bekas perokok dengan Index Brinkman ringan).

\footnotetext{
Correspondence:

Mega Senja, Departemen Pulmonologi, dan Kedokteran Respirasi Fakultas Kedokteran Universitas Andalas/RSUP DR. M. Djamil, Padang, Indonesia Email:megasenja.dr@gmail.com
} 
Dari pemeriksaan fisik didapatkan keadaan umum pasien tampak sakit sedang dengan kesadaran compos mentis cooperative. Tanda vital di dapatkan hasil tekanan darah $110 / 70 \mathrm{mmHg}$, nadi $86 x / \mathrm{m}$, napas $21 \mathrm{x} / \mathrm{m}$, dan suhu $37,1^{\circ} \mathrm{C}$. Pada pemeriksaan mata, leher, thorak, jantung, dan abdomen didapatkan hasil dalam batas normal. Hasil pemeriksaan penunjang didapatkan $\mathrm{Hb} 12,8 \mathrm{~g} / \mathrm{dL}$; leukosit $12.17010^{3} / \mu \mathrm{l}$; trombosit 350.000; hematokrit 39; GDS $122 \mathrm{mg} / \mathrm{dL}$, urea 19 $\mathrm{mg} / \mathrm{dL}$; kreatinin 1,0 U/L. Kemudian, pasien dilanjutkan dengan pemeriksaan TCM yang menghasilkan kesimpulan bahwa MTB not detected pada sample pasien. Dilanjutkan pemeriksaan BTA sebanyak dua kali dengan hasil negatif pada kedua pemeriksaan.

Pemeriksaan kultur dilakukan pada pasien sebanyak tiga kali. Pada pemeriksaan pertama, hasil yang didapatkan pada sampel adalah positif Aspergillus sp, pada kultur kedua dihasilkan kesimpulan No growth, dan kultur ketiga, didapatkan pertumbuhan dari Candida sp. CT scan thorak pasien ini didapatkan gambaran Aspergilloma dengan bullae serta bronkiektasis (gambar 2). Bronkoskopi dilakukan untuk membantu dalam penegakan diagnosis. Hasil bronkoskopi menunjukkan adanya pendarahan berasal dari segmen anterior BUKI (gambar3).

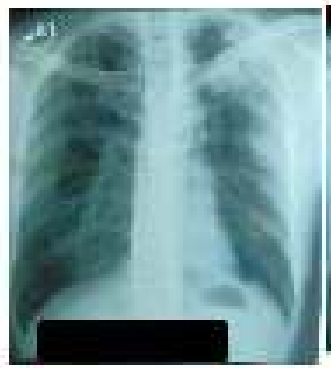

A

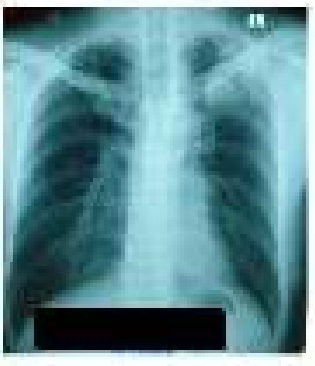

[3.

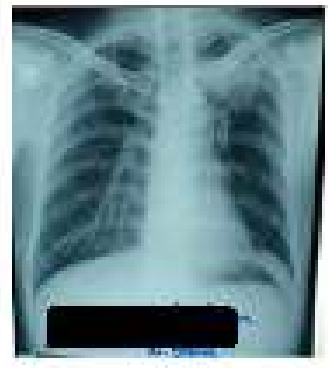

C

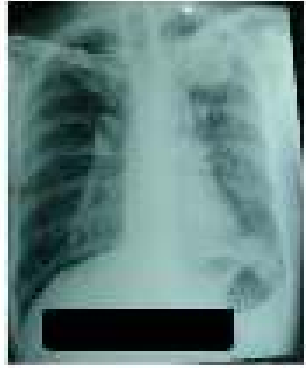

D

Gambar 1. Rontgen Toraks Pasien

Pasien dilakukan pemeriksaan rontgen thorak, seperti yang ditunjukkan pada gambar 1. Pada gambaran rontgen thorak (gambar AD), tampak kavitas dengan gambaran nodul opak didalamnya disertai fibrosis di sekitar lapangan paru bawah kiri menunjukkan kesan bekas $\mathrm{Tb}$ dengan fungus ball di apeks paru kiri. Pada gambar A, pasien dirawat dengan keluhan hemaptoe masif, foto B dan C adalah evaluasi rontgen thorak ketika kontrol ke poli, pasien mendapatkan obat anti jamur flukonazol 1x150mg, tetapi tidak diminum teratur. Dari rontgen thorak masih tampak gambaran fungus ball. Gambar D adalah rontgen thorak pasien dirawat kembali di bangsal paru dengan keluhan batuk darah masif. Pasien sebelumnya sudah di MDT kan dengan rencana lobektomi. Pasien sebelumnya sudah direncanakan untuk dilakukan operasi. Sebelum tanggal operasi, pasien masuk lagi pada rawatan sekarang dengan keluhan hemaptoe masif.

Dari gambaran CT scan thorak tanggal tampak fibroinfiltrat dan lesi noduler disertai gambaran halo dengan ukuran 5,9x4, 86x6,99cm di lapangan atas paru kiri, tampak pula lesi hipodens bulat-bulat multiple hampir 
seluruh lapangan paru/perselubungan kedua paru. Kesan dari pemeriksaan ini adalah aspergilloma dengan bullae serta bronkiektasis (gambar 2). Hasil bronkoskopi didapatkan hasil BUKI tampak lumen terbuka, mukosa licin, tidak hiperemis, tampak darah dan bekuan darah menutupi lumen pada segmen anterior, segmen apikoposterior, mukosa licin. Kesan dari bronkoskopi adalah tampak pendarahan berasal dari segmen anterior (gambar 3). Pasien dirawat inap di rumah sakit selama 14 hari. Pada hari rawatan ke 9, telah dilakukan lobektomi paru superior paru kiri. Jaringan post lobektomi (gambar 4) tampak jaringan kecoklatan, kenyal padat ukuran $3,5 \times 3,5 \times 2 \mathrm{~cm}$ penampang kecoklatan dan sepotong jaringan paru 1 lobus kecoklatan, kenyal padat, ukuran $10 \times 4 \times 4 \mathrm{~cm}$ penampang kecoklatan.
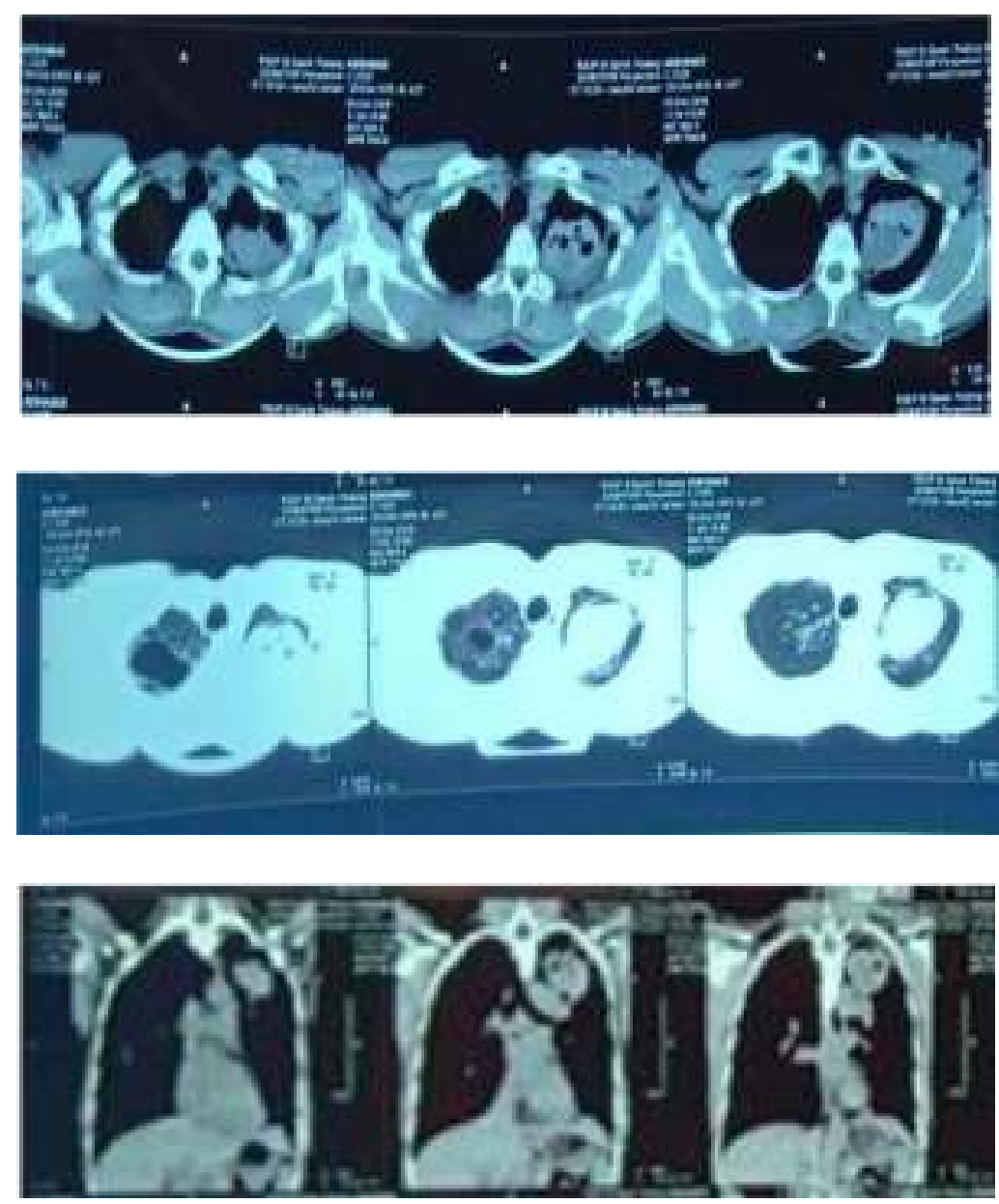

Gambar 2. CT scan thorak. 

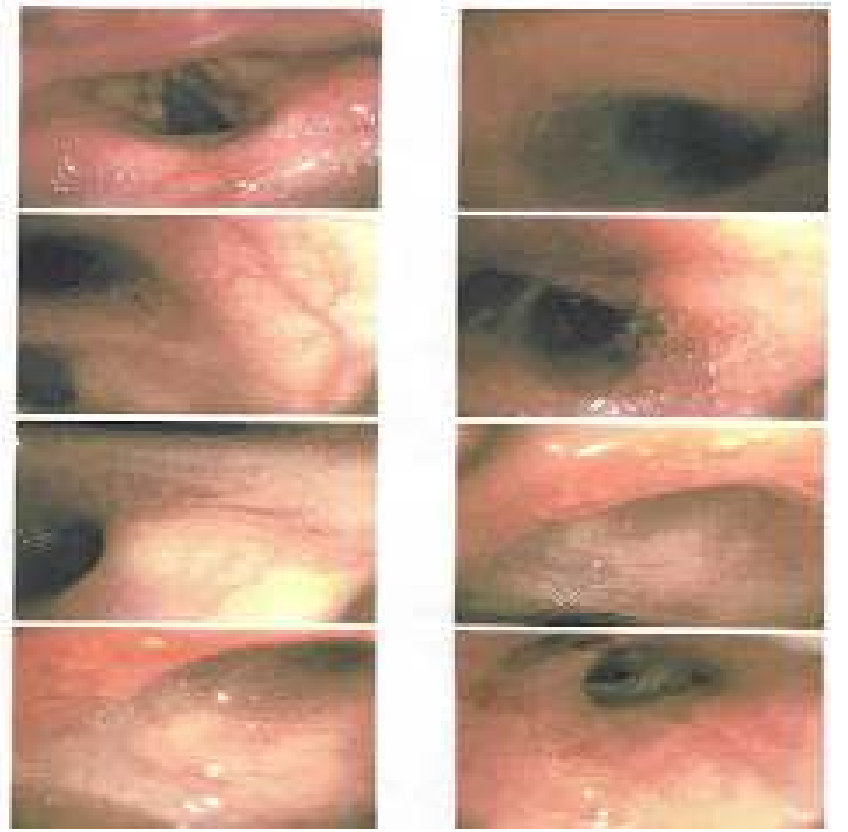

Gambar 3. Hasil bronkoskopi.

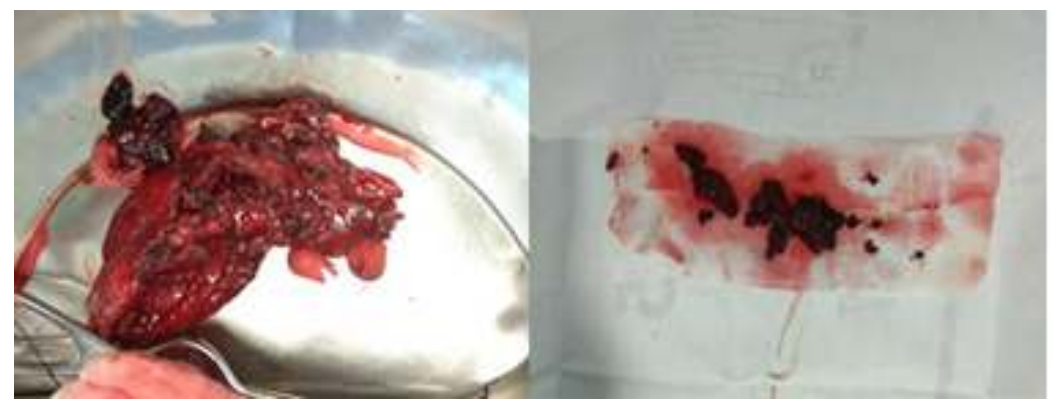

Gambar 4. Jaringan post lobektomi.

Jaringan kemudian dilakukan pemeriksaan histopatologi. Dari label aspergillloma mikroskopik tanpka potongan-potongan jaringan terdiri dari perdarahan, jaringan nekrotik, serta fungus ball. Fungus ball terdiri atas hifahifa jamur dengan bentukan septa yang bersudut. Diagnosa untuk jaringan ini adalah Fungus ball ec Infeksi Aspergillus (aspergilloma). Kemudian dari label paru mikroskopik tampak potongan-potongan jaringan bronkus dengan dengan permukaan dilapisi epitel respiratorius yang sebagian mengalami metaplasia skuamosa mengandung tulang rawan, kelenjar dengan permukaan dilapisi epitel kuboid. Stroma mengandung sebukan padat dan kelompokan sel-sel limfosit dan sel plasma. Pada satu bagian tampak kelompokan hifa jamur dengan bentukan septa yang bersudut. Pada bagian lain tampak jaringan paru terdiri atas alveoli-alveoli dengan permukaan dilapisi epitel kuboid, lumen berisi eritrosi, serta jaringan ikat mengandung sebukan padat dan kelompokan sel-sel limfosit, sel plasma, histiosit. Diagnosa radang kronik ec infeksi jamur aspergilus sp.

\section{DISKUSI}

Aspergilloma paru adalah salah satu penyakit infeksi jamur yang disebabkan oleh spesies saprofitik, genus aspergillus yang banyak terdapat di alam. Aspergiloma paru ini berupa 
kolonisasi di dalam kavitas paru yang dapat disebabkan oleh berbagai panyakit dasar. Kolonisasi ini membentuk formasi seperti massa yang disebut fungus ball atau mycetoma. Aspergiloma terdiri atas massa fungi, sel-sel epitel inflamasi, fibrin, dan debris jaringan. Jamur aspergillus terutama spesies Aspergillus fumigatus adalah jamur yang paling sering menyebabkan aspergiloma, jenis lain yang juga menyebabkan aspergilloma seperti Zygomycetes dan Fusarium, walaupun angka kejadiannya tidak sebanyak Aspergillus fumigatus (Brik A et al., 2008).

Pada pasien ini terdapat riwayat $\mathrm{Tb}$ paru 8 tahun sebelumnya dan minum obat sampai sembuh. Keluhan batuk darah mulai dirasakan sejak 4 tahun yang lalu, tetapi jumlah hanya sedikit, lengket di dahak. Disebutkan bahwa Aspergilloma sering ditemui pada pasien-pasien paska infeksi tuberkulosis paru, baik yang baru sembuh maupun yang telah sembuh dalam periode waktu yang lama. Sebagian besar studi melaporkan kavitas paru pada aspergilloma sebagian besar (13-89\%) disebabkan oleh tuberculosis (Demir et al., 2006).

Kekebalan pada host akan mempengaruhi infeksi oleh spesies Aspergillus. Pada individu yang imunokompeten dapat melakukan eliminasi secara efektif terhadap konidia Aspergillus yang terhirup. Terdapat 2 kelompok penderita yang berisiko berkembang menjadi infeksi jamur saprofit ini, antara lain adalah pada penderita yang mengalami gangguan kekebalan tubuh dan pada penderita yang memiliki penyakit kronis atau destroyed lung, pada kondisis ini terdapat kerusakan mekanisme pertahanan lokal bronkopulmoner (Hayes GE et al., 2016).

Gejala klinis yang ditemukan bervariasi, dapat asimptomatik sampai batuk darah yang mengancam nyawa. Sebagian besar kasus aspergilloma tidak menunjukkan gejala. Sekalipun ada gejala klinis biasanya tidak spesisfik, seperti batuk, dispneu, kelemahan umum, demam yang mungkin lebih terkait dengan penyakit paru yang mendasarinya. Batuk darah dapat terjadi mulai ringan sampai masif. Batuk darah yang berulang terjadi pada dua pertiga dari kasus aspergilloma. Tingkat kematian akibat hemoptisis yang berhubungan dengan aspergilloma berkisar 2-14\%. Kemungkinan penyebab batuk darah adalah karena adanya erosi (invasi lokal) pada pembuluh darah yang melapisis rongga, iritasi mekanis pada pembuluh darah yang terbuka pada kavitas, pelepasan endotoksin hemolitik dan enzim proteolitik seperti trypsin oleh jamur, infeksi bakteri akut yang terjadi bersamaan (Daly RC et al., 1986).

Pada pasien terdapat batuk darah masif dan berulang dalam 6 bulan. Tercatat selama 6 bulan pasien sudah dirawat 3 kali dengan keluhan utama batuk darah. Batuk darah pada pasien ini bersifat masif. Ukuran lesi pada pasien ini cenderung bertambah, jika dilihat perbandingan pada rontgen thorak. Pasein ini tidak ditemukan keadaan imunosupresi (tidak ada pemakaian kortikosteroid jangka panjang dan tidak ada infeksi HIV).

Prognosa aspergilloma dapat diprediksi buruk jika didapatkan peningkatan ukuran atau jumlah lesi seperti yang terlihat pada radiografi dada, imunosupresi (termasuk terapi kortikosteroid dan infeksi HIV), peningkatan titer IgG spesifik 
Aspergillus, sarkoidosis hemoptisis masif dan berulang.

Diagnosis biasanya ditegakkan berdasarkan gejala klinis dan pemeriksaan radiologi (foto thorak dan CT Scan thorak) serta bukti serologis antibodi atau mikrobiologis dari Aspergillus spp. Pemeriksaan foto thoraks merupakan pemeriksaan pertama yang dilakukan ketika ada kecurigaan untuk kelainan penyakit paru. Dalam kasus aspergilloma, pada pemeriksaan foto thorak dapat ditemukan massa didalam kavitas, dengan tanda bulan sabit dimana ada ruang udara berbentuk bulan sabit yang memisahkan bola jamur dari dinding dada. Kelainan ini banyak ditemukan di lobus atas paru dan merupakan karekteristik dari aspergilloma. Saat perubahan posisi penderita maka bola jamur tersebut juga akan bergerak (Chamilos G et al., 2008).

CT scan thorak dapat membantu menegakkan diagnosis jika gambaran foto thorak kurang mendukung untuk diagnosis. Pada CT scan thorak gelembung gas sering terlihat didalam fungus ball. Penampilan radiologis ini dapat dilihat pada kondisi lain seperti neoplasma, abses paru, kista hidatidosa yang pecah, cavitating Wegener's granulomatosis, bekuan darah pada kavitas yang sudah aada sebelumnya. CT angiografi dapat dilakukan pada pasien dengan hemoptisis untuk mengidentifikasi arteri bronkial hipertrofik yang mensuplai darah pada dinding kistik aspergilloma (Chamilos Get al., 2008).

Pada pasien ini dilakukan rontgen thorak, CT scan thorak, kultur sputum dan semuanya mengarah ke aspergilloma. Tes laboratorium serologis tidak dilakukan karena tidak tersedia di rumah sakit kami.
Ketersediaan tes yang diperlukan untuk diagnosis pasti aspergilloma masih belum tersedia secara menyeluruh, dan jika tersedia biasanya memerlukan biaya yang tidak murah.

Tidak ada kesepakatan umum untuk penanganan aspergilloma paru. Pembedahan merupakan terapi definitif untuk aspergilloma. Pada pasien hemoptisis dianjurkan tirah baring, postural drainage atau terapi simptomatik lain. Pada pasien hemoptisis berulang atau massif, pembedahan dilakukan dengan mempertimbangkan risiko/toleransi operasi. Jika tidak mungkin dilakukan, dapat dipertimbangkan tindakan embolisasi atau pemberian OAJ transtorakal-intrakavitas (Rozaliyani et al., 2017).

Pada pasien yang tidak bisa dilakukan pembedahan dapat dilakukan instilasi endobronkial dan injeksi perkutaneus amphotericin. Dosis 10-20mg amphotericin (dilarutka 10$20 \mathrm{ml}$ aquabides) untuk instilasi memberikan hasil yang baik. Tindakan ini dilakukan selama 2-3x/minggu selama 6 minggu. Pemberian dosis yang lebih besar 40-50mg dapat digunakan untuk instilasi perkutaneus ke kavitas paru dengan bantuan alat kateter perkutaneus. Sedangkan peran pemberian amphotericin B secara intravena dari beberapa studi yang dilakukan, tidak memberikan manfaat (Patterson KC, 2014).

Dari beberapa studi menyebutkan peran pemberian obat anti jamur Itrakonazol oral dapat memberikan perbaikan klinis dan radiologi. Dosis yang digunakan adalah 200-400mg/hari selama 6-18 bulan. OAJ lain yang dianjurkan adalah varikanazol 150-200mg 2x/hari an posaconazole $300 \mathrm{mg} 1 \mathrm{x} /$ hari. 
Pada pasien ini terjadi batuk masif dan berulang sehingga perlu dipertimbangkan untuk tindakan pembedahan. Pasien sudah diberikan obat anti jamur (flukonazol) sebelumnya, tetapi pasien tidak minum teratur dan tidak ada perubahan yang berarti dari klinis dan rontgen thorak. Beberapa penelitian menyebutkan pemberian itrakonazol oral dapat memberikan perbaikan secara klinis dan radiologi. Dosis yang dianjurkan adalah 200-400mg/hari selama 6-18 bulan. Kelemahan itrakonazol adalah memiliki waktu kerja yang lama untuk memberikan efek dan seringkali terjadi kekambuhan jika obat dihentikan. Pada pasien ini diberikan terapi anti jamur dengan fluconazole karena itrakonazol tidak tersedia dan tidak ditanggung oleh BPJS Kesehatan. Pasien dilakukan spirometry sebelum dilakukan pembedahan, hasil didapatkan FEV1act/FEV1 pred <60\%, KVPact/KVPpred $\quad<60 \%$ sehingga resiko reseksi paru unilateral pada pasien ini berat. Tetapi hasil yang didapatkan tersebut juga didasarkan kepada effort pasien yang tidak maksimal ketika dilakukan spirometri.

\section{KESIMPULAN}

Pada laporan kasus ini, penulis menyajikan data kasus dari seorang laki-laki berusia 42 tahun yang telah didiagnosis sebagai aspergilloma paru. Pada pasien ini terjadi batuk masif dan berulang sehingga perlu dipertimbangkan untuk tindakan pembedahan. Pasien juga diberikan terapi anti jamur, yaitu flukonazol dengan dosis $1 \times 150 \mathrm{mg}$.

\section{KEPUSTAKAAN}

Barnes PD, Marr KA 2016. Aspergillosis: Spectrum of diasease, diagnosis, and treatment. Infectious Disease Clinics of North America. 2016; 20: 545-561.

Brik A, Salam AM, Kamal A, Sadek MA, Essa m, Sharawi M et al., 2008. Surgical outcome of pulmonary aspergilloma. European Journal of Cardio-thoracic Surgery 2008; 34: 882-5.

Chamilos G, Kontoyiannis DP 2008. Aspergillus, candida, and other opportunistic mold infections of the lung. Fishman AP, Elias JA, Fishman JA, Grippi MA, Senior RM et al. Fishman's pulmonary diseases and disorders. Edisi 4. Philadelphia: McGraw-Hill, 2008.h. 2291-2313.

Daly RC, Pairolero PC, Piehler JM 1986. Pulmonary Aspergilloma. Result of Surgical Treatment. J Thorac Cardiovasc Surg 1986; 92: 981-988.

Demir A, Gunluoglu MZ, Turna A, Kara H, Dincer SI 2006. Analysis of surgical treatment for pulmonary aspergilloma. Asian Cardiovasc Thorac Ann 2006; 14: 407-411.

Garvey J, Crastnoopol P, Weisz D 1977. The Surgical Treatment of Pulmonary Aspergilloma. J thorac Cardivasc Surg 1977: 74:542-547.

Gefter WB 1992. The spectrum of Pulmonary Aspergillosis. J Thorac Imaging. 1992; 7; 56-74.

Hayes GE, Frazer LN 2016. Chronic Pulmonary Aspergillosis; Where are we, and where are we going. Fungi.2016;2(18):1-3.

Hohl TM, Feldmesser M 2007. Aspergillus fumigatus: Principles of pathogenesis and host defense. Eukaryotic Cell. 2007; 6(11): 1953-1963.

Karas A, hankins JR, Attar S 1976. Pulmonary Aspergillosis; an Analysis of 41 patient. Ann Thorac Surg 1976; 22 : 1-7.

Kawamura S, MaesakiS, Tomuno K et al., 2002. Clinical evaluation of 61 patients with pulmonary 
aspergilloma, In Med. 39 (2002); 209212.

Kurul IC, Demircan S, Yazici U, Altinok T, Topcu S, Unlu M 2004. Surgical management of pulmonary aspergilloma. Asian Cardiovasc Thorac Ann 2004; 12: 320-323.

Lee JG, Park IK, Kim DJ, Chang J, Kim SK, Chung KY 2009. Pulmonary aspergilloma: analysis of prognosis in relation to symptom and treatment, J Thorac Cardiovasc Surg 138: 820-825. 2009

Moodley L, Pillay j, Dheda K 2014. Aspergilloma and the surgeon. J Thorac Dis 2014: 6(3): 202-209.

Nguyen MH, Jaber R, Leather HL et al., 2007. Use bronchoalveolar lavage to detect galactomannan for diagnosis of pulmonary aspergillosis amon nonimmunocompromised hosts, J. Clin. Microbiol. 45 (2007) 2787-2792.

Panda BN. Fungal infection of Lungs. The Emerging Scenario. Indian Journal of Tuberculosis

Park SY, Lee SO, Choi SH et al., 2011. Serum and bronchoalveolar lavage fluid galactomannan assays in patients with pulmonary aspergilloma, Clin. Infect. Dis. 52 (2011) 149-152.

Park S, Mehrad B. Innate imunity to aspergillus species. Clinical microbiology reviews. 2009; 22(4): 535551.

Passera E, Rizzi A, Robustellini M, Rossi G, Pona CD et al., 2012. Pulmonary aspergilloma: Clinical aspects and surgical treatment outcome. Thorac Surg Clin. 2012; 22: 345-361.

Patterson f, Thompson G, Denning D et al., 2016. Clinical Infectious disease. Practice Guidelines for the Diagnosis and Managemen of Aspergillosis. Update by IDSA. 2016.

Patterson KC, strek ME 2014. Diagnosis and Treatmentv of Pulmonary Aspergillosis syndrome. Chest. 2014 November: 146(5): 1358-1368.

Pratap H, dewan RK, Singh L, Gill S, Vaddadi S 2007. Surgical treatment of pulmonary aspergilloma: a series of 72 cases. The Indian Journal of Chest Diseases \& Allied Sciences 2007; 49: 23-8.

Richardson MD, Warnock DW 1993. Fungal Infection: diagnosis and Management. Blackwell Scientific publication: 1993.

Rozaliyani A, Jusuf A, Handayani D, Syahruddin E, Burhan E, Isbaniyah F 2017. Mikosis paru. Pedoman nasional Untuk Diagnosis dan Penatalaksanaan di Indonesia. PDPI. Jakarta. 2017. 